\title{
Pengaruh kitosan terhadap peningkatan level ekspresi WRKY17 dan WRKY53 tanaman Capsicum annuum cv. Laba pada kondisi kekeringan
}

\author{
The effect of chitosan on the escalation of WRKY17 and WRKY53 genes expression level on Capsicum \\ annuum $c v$. Laba under drought condition \\ Muhammad Abdul AZIZ1)*, Rizkita Rachmi ESYANTI'2), \& Fenny Martha DWIVANNY²)3 \\ 1) Pusat Penelitian Bioteknologi dan Bioindustri Indonesia, Jl. Taman Kencana No. 1 Bogor, Indonesia 16128 \\ 2) Sekolah Ilmu dan Teknologi Hayati, Institut Teknologi Bandung, Jl. Ganeca 10, Bandung, Jawa Barat, Indonesia \\ 3) Pusat Penelitian Nanosains and Nanoteknologi, Institut Teknologi Bandung, Jawa Barat, Indonesia
}

Diterima tgl 26 Mei 2020 / disetujui tgl 19 Oktober 2020

\begin{abstract}
Chitosan is known as the natural plant growth biostimulant and defense elicitor involving WRKY transcription factors in response to environmental stresses. However, either plant's growth or defense responses against stress are different among the cultivars. In the previous study, chitosan and drought treatment combination on red chili plant cv. Lado resulted in the impeded growth performance followed by the down-regulated expression level of WRKY17. Hence, this study aimed to investigate the response of red chili plant from the different cultivar towards the combination of chitosan and drought treatments. At the onset of the generative phase, plants were subjected to the drought treatment with and without $1 \mathrm{mg} \mathrm{mL}^{-1}$ of chitosan application. Observation of plant growth performance was carried out by measuring plant height, the number of leaves, the conversion percentage of flowers developed to fruits, and the number of harvested fruits, while the molecular parameter was indicated by the analyses of WRKY17 and WRKY53 expression levels. In line with the previous study using $c v$. Lado, the combination of $1 \mathrm{mg} \mathrm{mL}^{-1}$ of chitosan and drought treatment significantly reduced the plant productivity observed in the number of fruits, followed by the plant height and the number of leaves. However, the expression level of WRKY17 and WRKY53 experienced 10 and 22-fold higher than controls, respectively. This is different from the previous study which showed the reduction of WRKY17 expression level. According to the study, it can be implied that the combination of chitosan and drought treatments on red chili plant cv. Laba could reduce plant growth performance, but increased genetics indicator towards plant's defense system against stress indicated by the escalation of WRKY17 and WRKY53 expression level. Furthermore, the individual chitosan application are potential to increase the productivity of red chili plant cv. Laba.
\end{abstract}

[Keywords: red chili cv. Laba, gene expression, growth performance]

\begin{abstract}
Abstrak
Kitosan diketahui merupakan biostimulan pertumbuhan dan elisitor ketahanan alami yang melibatkan faktor transkripsi WRKY dalam merespons stres lingkungan. Sementara itu, dalam menanggapi cekaman, respons pertumbuhan maupun ketahanan tanaman berbeda pada kultivar satu dan yang lain. Pada penelitian sebelumnya, kombinasi kitosan dan kekeringan pada cabai merah cv. Lado berdampak pada penurunan karakter pertumbuhan yang diikuti penurunan level ekspresi WRKY17. Dengan demikian, penelitian ini bertujuan untuk mempelajari respons tanaman cabai merah pada kultivar yang berbeda terhadap kombinasi perlakuan kitosan dan kekeringan. Ketika memasuki fase generatif, tanaman diberikan cekaman kekeringan dengan dan tanpa perlakuan kitosan $1 \mathrm{mg} \mathrm{mL}^{-1}$. Pengamatan karakter pertumbuhan dilakukan dengan mengukur tinggi, jumlah daun, persentase konversi bunga menjadi buah dan jumlah buah, sedangkan analisis molekuler dilakukan dengan mengkuantifikasi level ekspresi WRKY17 dan WRKY53. Sejalan dengan hasil penelitian sebelumnya pada cv. Lado, kombinasi perlakuan kitosan dan kekeringan secara signifikan dapat menurunkan produktivitas tanaman cabai merah cv. Laba yang teramati pada parameter jumlah buah, kemudian diikuti parameter tinggi tanaman dan jumlah daun. Namun, level ekspresi WRKY17 dan WRKY53 secara berturut-turut mengalami peningkatan sebesar 10 dan 22 kali lipat lebih tinggi dibandingkan kontrol. Hal tersebut berlawanan dengan hasil sebelumnya yang mana menunjukkan penurunan level ekspresi WRKY17. Berdasarkan hasil tersebut dapat disimpulkan bahwa kombinasi perlakuan kitosan dan kekeringan pada cv. Laba dapat menurunkan respons pertumbuhan, namun meningkatkan indikator genetik ketahanan tanaman terhadap cekaman yang ditunjukkan dengan peningkatan level ekspresi WRKY17 dan WRKY53. Sementara
\end{abstract}

*) Penulis korespondensi: azizuad@gmail.com 
itu, aplikasi kitosan secara individu berpotensi meningkatkan produktivitas tanaman cabai merah cv. Laba.

[Kata kunci: cabai merah cv. Laba, ekspresi gen, performa pertumbuhan]

\section{Pendahuluan}

Kitosan merupakan turunan dari kitin, yaitu polisakarida yang umumnya ditemukan pada eksoskeleton udang, lobster, dan kepiting (Mondal et al., 2012). Senyawa ini merupakan co-polymer dari $N$-acetyl-D-glucosamine, dan $D$-glucosamine (Pichyangkura \& Chadchawan, 2015). Kitosan banyak dipelajari sebagai biostimulan untuk meningkatkan pertumbuhan tanaman. Selain itu, kitosan diketahui memiliki aktivitas antifungi, antitranspiran, dan elisitor ketahanan terhadap cekaman biotik maupun abiotik (Ohta et al., 2004; Dzung et al., 2011; \& Mondal et al., 2012). Beberapa penelitian sebelumnya menyatakan bahwa aplikasi kitosan saat cekaman kekeringan dilaporkan dapat meningkatkan karakter fisiologis tanaman Richinus communis (Karimi et al., 2012) dan Ocimum basilium (Malekpoor et al., 2016). Namun demikian, Bistgani et al. (2017) menyatakan bahwa aplikasi kitosan pada kondisi kekeringan $50 \%$ menyebabkan penurunan berat basah tanaman Thymus. Aziz et al. (2020) menambahkan bahwa aplikasi kitosan pada tanaman cabai merah cv. Lado saat kekeringan secara signifikan dapat menurunkan pertumbuhan yang diikuti penurunan level ekspresi WRKYI7. Dengan demikian, dapat diketahui bahwa aplikasi kitosan pada berbagai kondisi lingkungan terhadap berbagai jenis hingga kultivar tanaman menunjukkan pengaruh yang beragam.

Kekeringan merupakan salah satu stres abiotik yang menjadi masalah paling besar di bidang pertanian karena dapat menghambat pertumbuhan dan menurunkan produktivitas tanaman. Secara umum, tanaman akan merespons cekaman kekeringan dengan mensintesis asam absisat (ABA), fitohormon terkait perkembangan tanaman dan juga sebagai salah satu regulator ketahanan. ABA kemudian mengaktifkan jalur transduksi signal yang melibatkan sintesis senyawa-senyawa oksidatif seperti $\mathrm{H}_{2} \mathrm{O}_{2}$ untuk menginduksi penutupan stomata sebegai salah satu mekanisme pertahanan. Hal tersebut bertujuan untuk mengurangi laju transpirasi, namun sayangnya juga berdampak pada penurunan laju fotosintesis seiring menurunnya suplai $\mathrm{CO}_{2}$, sehingga hal ini berakibat pada penurunan pertumbuhan dan produktivitas tanaman (Iriti et al., 2009; Anjum et al., 2011; Phimchan et al., 2012). Saat tercekam, tanaman dapat melakukan berbagai mekanisme adaptif yang melibatkan integrasi molekuler dalam mengaktifkan transduksi sinyal untuk mempertahankan pertumbuhan dan/ atau ketahanan (Khan et al., 2014). Yan et al. (2014) menyatakan bahwa sensitivitas tanaman terhadap cekaman kekeringan melibatkan faktor transkripsi WRKY dalam mengaktifkan jalur signaling ABA yang memicu penutupan stomata.

WRKYs merupakan salah satu kelompok faktor transkripsi yang dikarakterisasi berdasarkan keberadaan satu atau dua domain pada sisi $\mathrm{N}$ dan C terminal, yaitu dengan motif WRKYGQK pada sisi $\mathrm{N}$ terminal dan motif zinc finger pada sisi $\mathrm{C}$ terminal. Kedua elemen tersebut dibutuhkan untuk afinitas pengikatan protein WRKY dengan sekuen konsensusnya, $\mathrm{C} / \mathrm{T}) \mathrm{TGAC}(\mathrm{C} / \mathrm{T}$, yang disebut $W$ box pada daerah promoter gen target. Terdapat 74 protein WRKY yang dikarakterisasi dari Arabidopsis dan telah dikelompokkan ke dalam tiga grup berdasarkan jumlah dan tipe domain WRKYnya. Grup III dicirikan dengan satu motif C-C-H-C zinc finger, grup II dicirikan dengan satu motif C-C-H-H zinc finger, dan grup I dicirikan dengan dua motif C-C-H-H zinc finger (JournotCatalino et al., 2006). WRKY diketahui berperan dalam jalur signaling asam absisat (ABA) dan asam jasmonat (JA) pada tanaman dalam merespons cekaman kekeringan (Jiang et al., 2015; Ding et al., 2014). Namun demikian, belum banyak studi yang mempelajari peran WRKY dalam merespons cekaman kekeringan pada berbagai komoditas pertanian khususnya tanaman cabai merah.

Di Indonesia, produksi komoditas cabai dari waktu ke waktu cenderung fluktuatif bahkan sering kali tidak dapat memenuhi kebutuhan pasar. Hal tersebut terjadi baik karena adanya paparan cekaman biotik seperti infeksi patogen maupun abiotik seperti kekeringan (Balitbang, 2016; Kementerian Pertanian, 2016). Respons tanaman cabai merah dalam menanggapi cekaman lingkungan dipengaruhi oleh karakter pertumbuhan maupun ketahanan yang melekat pada masing-masing kultivar maupun variasi genetik. C. апnиum cv. Laba merupakan produk unggulan yang dikembangkan dari kultivar Lado oleh PT East West Seed Indonesia. Beberapa karakter yang dikembangkan meliputi peningkatan ketahanan terhadap berbagai penyakit dan masa panen yang lebih singkat (PT East West Seed Indonesia, unpublished). Pada penelitian sebelumnya, aplikasi kitosan saat kekeringan terhadap C. аппиит cv. Lado berdampak pada pertumbuhan dan produktivitas yang terhambat. Oleh sebab itu, pada penelitian ini digunakan kultivar Laba sebagai kelanjutan dari riset sebelumnya untuk mempelajari peran kitosan terhadap tanaman cabai merah pada kultivar yang berbeda. Keunggulan karakter ketahanan pada cv. Laba diharapkan dapat menyebabkan pengaruh positif terhadap kombinasi perlakuan kitosan dan kekeringan. Penelitian ini bertujuan untuk mempelajari respons tanaman cabai merah pada kultivar yang berbeda terhadap kombinasi perlakuan kitosan dan kekeringan. 


\section{Bahan dan Metode}

\section{Bahan dan pemeliharaan tanaman}

Pemeliharaan tanaman cabai merah dan perlakuan dilakukan di rumah kaca Institut Teknologi Bandung, Indonesia. Desain penelitian menggunakan rancangan acak kelompok (RAK) dengan serial perlakuan terdiri dari kelompok aplikasi kitosan (Chi), kombinasi kitosan dan kekeringan (Chi-D), kekeringan (D), dan kontrol (C) dengan tiga ulangan. Penelitian ini diawali dengan mempersiapkan media tanam yang terdiri dari campuran tanah, sekam dan pupuk kandang (4:3:2, v/v/v), kemudian dimasukkan ke dalam polybag berukuran 17,5 x $35 \mathrm{~cm}$ sebanyak $3 \mathrm{~kg}$. Bibit cabai merah berusia sekitar 3 minggu ditanam pada media dengan penyiraman normal atau sebesar $100 \%$ kapasitas lapang dari media yang digunakan (Restiana, 2016). Berdasarkan hasil perhitungan, jumlah air yang digunakan untuk memenuhi $100 \%$ kapasitas lapang yaitu $1 \mathrm{~L}$ untuk 2 hari, yang mana dilakukan hingga memasuki fase generatif. Sementara itu, larutan kitosan $1 \%$ disiapkan dengan cara melarutkan $5 \mathrm{~g}$ serbuk kitosan dalam 3,5 mL asam asetat glasial kemudian diencerkan dengan akuades hingga 500 $\mathrm{mL}$ dengan bantuan magnetic stirrer selama \pm 24 jam dan digunakan sebagai larutan stok. Ketika akan digunakan, kitosan $1 \mathrm{mg} \mathrm{mL}^{-1}$ dibuat dengan melarutkan $100 \mathrm{~mL}$ stok kitosan ke dalam $900 \mathrm{~mL}$ akuades dan dihomogenkan dengan bantuan magnetic strirrer pada kecepatan tinggi (500 rpm) sambil ditambahkan $\mathrm{NaOH} 3 \mathrm{M}$ sedikit demi sedikit hingga larutan mencapai pH $6-6,4$ (Esyanti et al., 2019).

Tanaman yang mulai memasuki fase generatif, yaitu ditandai dengan munculnya kuncup bunga, diberikan kombinasi perlakuan kitosan $1 \mathrm{mg} \mathrm{mL}^{-1}$ dan kekeringan. Perlakuan kekeringan dilakukan dengan cara mempertahankan media tanam dengan $50 \%$ kadar air dari kapasitas lapang (Dorji et al., 2005), yaitu dengan penyiraman sebanyak $500 \mathrm{~mL}$ air per 2 hari terhadap kelompok perlakuan Chi-D dan D. Sementara itu, perlakuan kitosan dilakukan dengan cara disemprotkan pada permukaan abaksial dan adaksial daun secara merata yang dilakukan satu kali dalam sepekan (Esyanti et al., 2019) pada kelompok perlakuan Chi-D dan Chi. Perlakuan ini berlangsung hingga memasuki masa dipanen, yaitu berkisar antara 55-60 hari setelah berbunga (Sung et al., 2005). Setelah dipanen, daun cabai langsung dibungkus dengan alumunium foil kemudian dicelupkan ke dalam nitrogen cair dan disimpan di dalam deep freezer $-80^{\circ} \mathrm{C}$ untuk digunakan pada analisis molekuler.

\section{Pengukuran parameter pertumbuhan}

Selama perlakuan dilakukan pengukuran terhadap parameter pertumbuhan yang terdiri dari tinggi tanaman, jumlah daun, persentase perubahan bunga menjadi buah, dan jumlah buah. Pengukuran tinggi tanaman dilakukan setiap minggu yaitu dengan mengukur tinggi mulai dari permukan tanah hingga ujung tanaman pada 8 hingga 16 minggu setelah tanam (MST) menggunakan mistar, sementara jumlah daun dan jumlah buah dihitung secara manual pada 16 MST. Persentase perubahan bunga menjadi buah dihitung dengan cara membagi jumlah buah saat panen (16 MST) dengan jumlah bunga pada titik tertinggi untuk masing-masing kelompok perlakuan.

\section{Ekstraksi RNA dan analisis qPCR}

Pada penelitian ini, RNA total diisolasi dari sampel daun sebanyak $50 \mathrm{mg}$ menggunakan kit mini PureLinkTM RNA (Thermoscientific Invitrogen). Integritas RNA dikonfirmasi dalam gel agarosa $1,5 \%(\mathrm{~b} / \mathrm{v})$ dengan gel red sebagai agensia pewarna menggunakan instrumen elektroforesis. Sementara itu, kuantitas dan kemurnian RNA diukur menggunakan spektrofotometer nanodrop (Eppendorf, bio-spectrometer) pada rasio penjang gelombang $\lambda_{260}$ dan $\lambda_{280}$. Perlakuan DNAse untuk memurnikan RNA dilakukan menggunakan DNAseI (Thermo Scientific), sedangkan sintesis cDNA dilakukan dengan iScript cDNA Synthesis Kit (Bio-Rad) yang mengandung enzim reverse transcriptase. Setelah itu, kualitas cDNA dikonfirmasi dalam gel agarosa 2\% menggunakan CaUbi3 sebagai gen referensi dengan primer spesifik yang telah didesai sebelumnya. Kondisi Reaksi PCR (standard PCR, thermal cycler) dilakukan dengan program sebagai berikut: $95^{\circ} \mathrm{C} 3$ menit, $95^{\circ} \mathrm{C} 30$ detik, $58^{\circ} \mathrm{C} 30$ detik, $72^{\circ} \mathrm{C} 1$ menit, $72^{\circ} \mathrm{C} 5$ menit sebanyak 35 siklus ( $\mathrm{n}=3$ ulangan teknis).

Amplifikasi gen WRKY17 (Accession number : XM_016699929.1) dan WRKY53 (Accession number : NM_001324692.1) dilakukan menggunakan primer spesifik yang merujuk dari penelitian sebelumnya oleh Aziz et al. (2020) yaitu dengan sekuen (5', ke 3') Forward : GGGGTTACTACAGATGCAGC dan Reverse : CTCTGGCCAGAACTTCCATC untuk WRKY17, serta sekuen Forward : ACAGATGCACGTATCGTCAC dan Reverse : GCCTGTTTTGATAAACGGCC untuk WRKY53. Sementara itu, primer yang digunakan untuk mengamplifikasi gene referensi CaUbi3 (Accession number : AY486137.1) yaitu menggunakan sekuen TCCATCTGCTCTCTGTTGACG (Forward) dan CCCCAAGCACAATAAGACATTGT (Reverse). Setelah dikonfirmasi menggunakan instrumen elektroforesis, sekuening dilakukan melalui jasa Macrogen, Korea. Pada tahap akhir, analisis quantitative PCR dilakukan dengan menggunakan instrumen dan perangkat lunak dari MyGo Pro dengan pewarna dari Toyobo (Thunderbirds Sybr qPCR Mix QPS-201). Skor siklus kuantifikasi (Cq) kemudian digunakan untuk mengukur level ekspresi melalui metode relatif dengan menggunakan rumus seperti yang dijelaskan oleh Livak \& Schmittgen (2001). 


\section{Analisis statistik}

Pengaruh kitosan, kekeringan, dan interaksi antar kedua perlakuan terhadap parameter jumlah daun, persentase bunga menjadi buah, jumlah buah, serta level ekspresi WRKY17 dan WRKY53 dianalisis dengan Two-way ANOVA yang dilakukan menggunakan aplikasi statistik IBM SPSS 22. Perbedaan signifikansi antar perlakuan dan analisis korelasi antar parameter ditentukan menggunakan uji Tukey HSD pada $P<0,05$ menggunakan aplikasi R studio 3.5.2 (64 bit).

\section{Hasil dan Pembahasan}

Pada penelitian ini, rata-rata kondisi mikroklimat yang teramati yaitu pada fotoperiode 12 jam, kelembaban 78,96\%, intensitas cahaya 10240 lux dan suhu $27,78^{\circ} \mathrm{C}$. Hasil pengamatan terhadap pertumbuhan tanaman cabai merah kultivar Laba yang dilakukan dengan mengukur tinggi tanaman dari 8 hingga 16 MST, jumlah daun dan buah pada 16 MST, serta persentase konversi bunga menjadi buah ditampilkan pada Gambar 1 . Hasil pengamatan tersebut menunjukkan adanya pengaruh kitosan yang signifikan terhadap pertumbuhan tanaman cabai merah pada kondisi kekeringan. Kitosan diketahui merupakan copolimer dari $N$-asetil-D-glukosamin dan $D$ glukosamin yang dapat menstimulasi pertumbuhan tanaman karena diperkirakan dapat menjadi sumber nitrogen (gugus amina) (El-Tanahy et al., 2012), meningkatkan penyerapan mikronutrien dan makronutrien (Chookhongkha et al., 2012; Jang et al., 2012), meningkatkan aktivitas enzimenzim terkait metabolisme nitrogen seperti nitrat reduktase, glutamin sintetase, dan protease serta meningkatkan transport nitrogen pada daun (Mondal et al., 2012).

Kekeringan merupakan salah satu cekaman abiotik yang dapat menstimulasi asam jasmonat (JA) dan menekan kerja hormon giberelin (GA), sehingga pertumbuhan tanaman terhambat. Selain itu, tanaman dapat merespons kekeringan dengan mengaktifkan asam absisat (ABA) yang dapat menginduksi penutupan stomata untuk mengurangi laju transpirasi (Iriti et al., 2009). Namun, hal tersebut juga berdampak pada penurunan absorbsi $\mathrm{CO}_{2}$, sehingga aktivitas fotosintesis menurun dan berakibat pada penurunan pertumbuhan dan kesintasan tanaman (Anjum et al., 2011; Phimchan et al., 2012). Peran kitosan dalam meningkatkan aspek fisiologis tanaman saat kekeringan telah dipelajari pada beberapa tanaman seperti Ocimum basilium (Malekpoor et al., 2016) dan Richinus communis (Karimi et al., 2012). Dengan demikian, kitosan diperkirakan juga dapat mempengaruhi aspek fisiologis maupun molekuler tanaman $C$. апnиum pada kondisi kekeringan.
Aplikasi kitosan saat kekeringan menurunkan pertumbuhan dan produktivitas tanaman

Pada parameter tinggi tanaman terjadi tren peningkatan tinggi mulai dari akhir fase eksponensial hingga fase stasioner (Gambar 1A). Pada 8 MST atau akhir fase eksponensial, tinggi tanaman pada setiap kelompok perlakuan memperlihatkan pola yang seragam, hal ini menunjukkan bahwa pola pertumbuhan tanaman pada fase vegetatif di setiap kelompok perlakuan relatif sama. Saat memasuki akhir fase stasioner atau 16 MSA, kelompok kombinasi perlakuan kitosan $1 \mathrm{mg} \mathrm{mL} \mathrm{m}^{-1}$ dan kekeringan (Chi-D) menunjukkan tren tinggi tanaman yang paling rendah dibanding kelompok lainnya. Sementara itu, kelompok kontrol (C) menunjukkan tren tinggi tanaman yang paling baik. Oleh sebab itu, diperkirakan bahwa aplikasi kitosan pada penelitian ini tidak menyeimbangkan dampak negatif dari cekaman kekeringan yang dialami tanaman cabai merah kultivar Laba. Hal tersebut sesuai dengan dugaan Iriti et al. (2009) bahwa kombinasi perlakuan kitosan dan kekeringan pada tanaman dapat menyebabkan respons sinergis dalam meningkatkan ketahanan terhadap cekaman namun berdampak antagonis terhadap pertumbuhan, yakni ditunjukkan dengan respon pertumbuhan yang terhambat.

Berdasarkan jumlah daun dan buah (Gambar 1B dan 1D) pada $16 \mathrm{MSA}$, terdapat tren yang relatif sama yaitu kelompok perlakuan kombinasi kitosan dan kekeringan (Chi-D) menunjukkan nilai yang paling rendah dibandingkan kelompok lainnya. Jumlah daun tertinggi teramati pada kelompok kitosan (Chi) yaitu sejumlah 182 helai, kemudian disusul kelompok perlakuan $\mathrm{C}, \mathrm{D}$, dan Chi-D secara berturut-turut 176, 101, dan 97 helai. Meskipun demikian, antara kelompok Chi dan C tidak berbeda signifikan, begitu pula antara kelompok D dan Chi-D. Selaras dengan jumlah daun, jumlah buah tertinggi juga teramati pada kelompok Chi yaitu sejumlah 28 buah, kemudian disusul C, D, dan Chi-D secara berturut-turut 21, 19, dan 15 buah. Namun, pada parameter jumlah buah, kelompok perlakuan Chi-D teramati paling rendah dan berbeda signifikan terhadap kelompok lainnya. Dengan demikian, kombinasi perlakuan kitosan dan kekeringan berpotensi menyebabkan pengaruh penurunan pertumbuhan dan produktivitas tanaman cabai merah. Meskipun demikian, aplikasi kitosan secara individu perpotensi untuk meningkatkan jumlah buah. Hasil ini selaras dengan studi Bistgani et al. (2017) bahwa aplikasi kitosan pada kondisi kekeringan $50 \%$ menyebabkan penurunan berat basah tanaman Thymus sekitar 29,98\% dan 5,60\% yang ditanam pada tahun 2014 dan 2015 secara berturutturut. Namun, hal tersebut tidak sejalan dengan hasil penelitian sebelumnya pada tanaman Ocimum basilium (Malekpoor et al., 2016) dan Richinus communis (Karimi et al., 2012). 
Perbedaan frekuensi aplikasi dan konsentrasi kitosan dapat menyebabkan perbedaan respons fisiologis pada tanaman. Malerba \& Cerena (2016) menyatakan bahwa aktivitas kitosan dalam menginduksi respons biologis tanaman seperti resistensi terhadap cekaman dan peningkatan produktivitas bergantung pada komposisi kimia, waktu aplikasi, dan frekuensi aplikasinya. Pada penelitian sebelumnya, tiga kali aplikasi kitosan dengan konsentrasi $0,4 \mathrm{~g} \mathrm{~L}^{-1}$ dapat meningkatkan pertumbuhan tanaman Ocimum basilicum baik pada kondisi normal maupun kekeringan (Malekpoor et al., 2016). Sementara itu, pada penelitian ini kitosan $1 \mathrm{mg} \mathrm{mL}^{-1}$ diaplikasikan selama fase generatif yaitu sejumlah 8 kali aplikasi, sehingga terdapat perbedaan frekuensi dan konsentrasi kitosan yang diduga menyebabkan perbedaan respons pada spesies yang berbeda. Oleh sebab itu, diperkirakan bahwa aplikasi kitosan $1 \mathrm{mg} \mathrm{mL}^{-1}$ pada fase generatif tidak berpengaruh signifikan dalam menyeimbangkan dampak negatif cekaman kekeringan. Selain itu, normalnya pada fase ini pertumbuhan tanaman memasuki fase stasioner, sehingga rendahnya jumlah daun dan buah pada kelompok perlakuan Chi-D dan D diduga disebabkan oleh gugurnya organ tanaman atau absisi. Penelitian sebelumnya menyatakan bahwa baik kekeringan maupun aplikasi kitosan diketahui dapat mengaktifkan jalur signaling yang sama, yaitu melalui sintesis asam absisat (ABA) yang memicu penutupan stomata dan absisi (Iriti et al., 2009; Golldack et al., 2014; Pichayangkura \& Chadchawan, 2015).

Absisi organ tanaman baik berupa daun, bunga maupun buah diduga disebabkan oleh cekaman kekeringan dan juga temperatur lingkungan yang teramati mencapai $31,48{ }^{\circ} \mathrm{C}$ pada $13 \mathrm{MST}$ (data tidak ditampilkan), sementara normalnya adalah $25-27^{\circ} \mathrm{C}$ pada siang hari dan $18-20{ }^{\circ} \mathrm{C}$ pada malam hari (Sumarni \& Muharam, 2005). Cekaman abiotik yang dialami tanaman selama fase generative akan berdampak signifikan terhadap gugurnya bunga maupun buah (Sung et al., 2005).
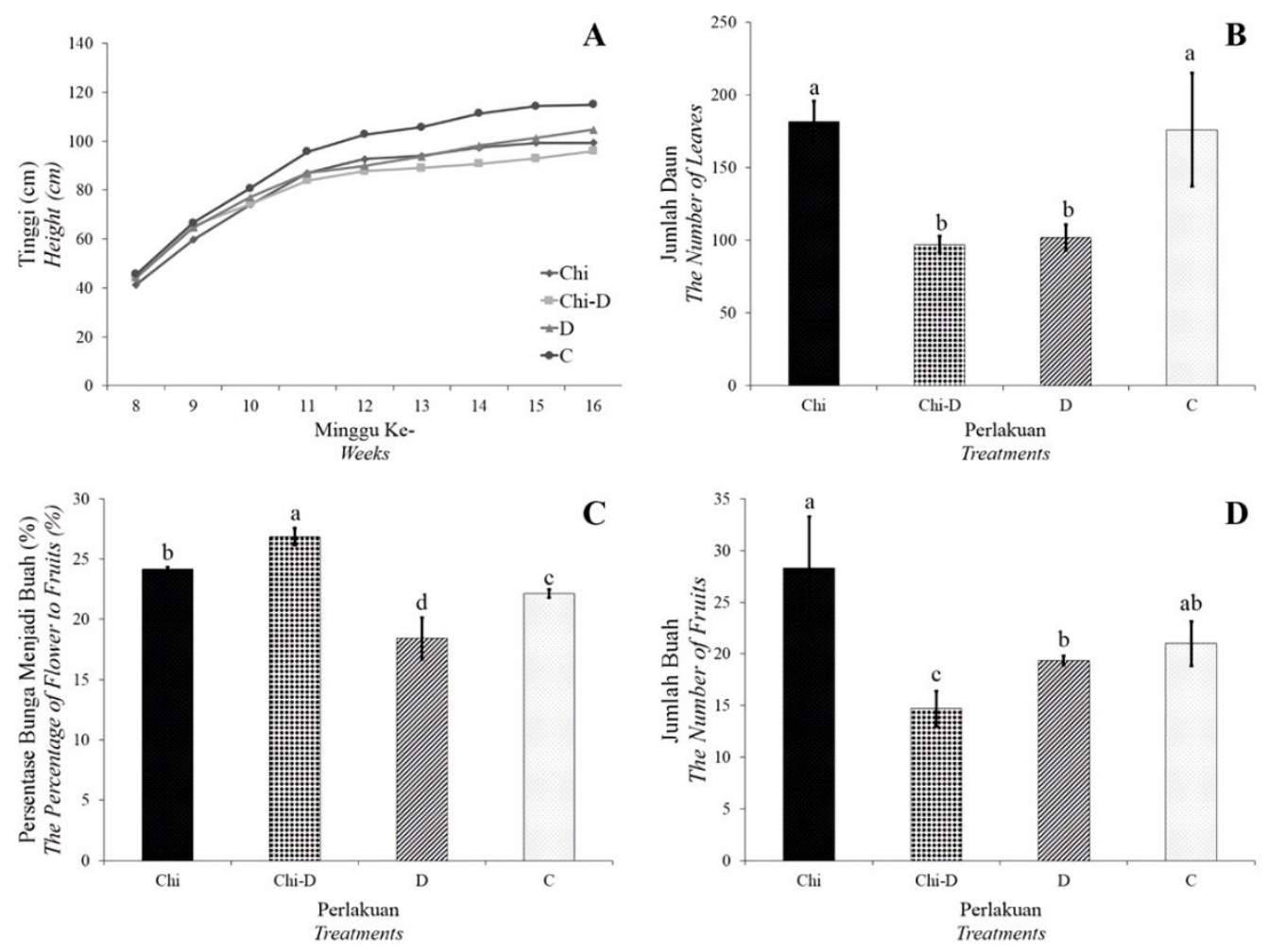

Gambar 1. Pertumbuhan dan produktivitas tanaman cabai merah yang terdiri dari (A) tren tinggi tanaman dari minggi ke 8 - 16, (B) jumlah daun, (C) persentase konversi perubahan bunga menjadi buah, dan (D) jumlah buah. Bar pada setiap kelompok perlakuan merepresentasikan standar eror dari nilai rata-rata $(\mathrm{n}=3)$. Nilai signifikan ditentukan oleh perbedaan huruf pada setiap bar, $p<0,05$. Chi $=1 \mathrm{mg} \mathrm{mL} \mathrm{m}^{-1}$ kitosan; Chi-D = $1 \mathrm{mg} \mathrm{mL}^{-1}$ kitosan dan kekeringan; $\mathrm{D}=$ kekeringan; $\mathrm{C}=$ kontrol

Figure 1. Red chili plant growth and productivity including (A) plant height starting from week 8 to 16, (B) Leaves number $(C)$ The percentage of flowers to fruits conversion, and $(D)$ harvested fruits number. The bars represent the mean of each growth parameters with corresponding standard error $(n=3)$. Significant value is indicated by the letter on top of each bar, $p<0,05$. Chi $=1 \mathrm{mg}$ $m L^{-1}$ chitosan; Chi-D = $1 \mathrm{mg} \mathrm{mL}^{-1}$ chitosan and drought; $D=$ drought; $C=$ control 
Aziz et al. (2020) menambahkan bahwa jumlah bunga yang diproduksi selama fase tersebut dapat berfluktuasi seiring ketersediaan nutrisi, terjadinya cekaman abiotik, hingga berkembang menjadi buah. Meskipun diketahui dapat menyebabkan pertumbuhan dan produktivitas tanaman terhambat, kelompok perlakuan Chi-D memiliki persentase perkembangan bunga menjadi buah paling tinggi dibandingkan kelompok perlakuan lain yaitu sebesar $26,36 \%$. Nilai tersebut berbeda signifikan terhadap kelompok Chi, C dan D, yang teramati sebesar 24,18\%; 22,15\%; dan 13,42\% secara berturut-turut. Dengan demikian dapat diketahui bahwa meskipun dengan jumlah bunga paling rendah, kelompok tanaman pada perlakuan Chi-D dapat mempertahankan jumlah bunga tersebut hingga berkembang menjadi buah yang siap dipanen. Oleh sebab itu, aplikasi kitosan $1 \mathrm{mg} \mathrm{mL} \mathrm{m}^{-1}$ pada kondisi kekeringan diketahui berpotensi menurunkan dampak negatif dari cekaman kekeringan pada parameter pembungaan. Dugaan ini didukung oleh Dzung et al. (2011) yang menyatakan bahwa aplikasi kitosan dapat menurunkan tingkat absisi buah kopi hingga $15,25 \%$ dibandingkan kontrol yang diikuti dengan peningkatan kadar klorofil, akumulasi mineral, dan pertumbuhan tanaman tersebut. Selain itu, Salachna \& Zawadzinska (2014) menambahkan bahwa aplikasi kitosan dapat mempercepat waktu pembungaan dan meningkatkan jumlah bunga pada kelompok tanaman Freesia. Sementara itu, Dorji et al. (2005) dan Sung et al. (2005) menyatakan bahwa kekeringan 50\% menyebabkan penurunan jumlah buah lebih dari $20 \%$ dan berat buah 22\% dibandingkan kontrol. Hal tersebut selaras dengan hasil penelitian ini bahwa persentase perkembangan bunga menjadi buah pada kelompok perlakuan dengan kitosan (Chi dan Chi-D) terjadi peningkatan, sementara pada kelompok kekeringan (D) terjadi penurunan yang signifikan terhadap kontrol.

Secara umum, baik parameter tinggi tanaman, jumlah daun, maupun jumlah buah, kelompok kombinasi perlakuan kitosan $1 \mathrm{mg} \mathrm{mL}^{-1}$ dan kekeringan (Chi-D) menyebabkan penurunan karakter pertumbuhan dibandingkan kontrol. Hal ini diduga karena frekuensi perlakuan kitosan yang terlalu sering, sehingga dapat memicu penutupan stomata dan produksi Reactive oxygen species (ROS) berlebih (Pichyangkura \& Chadchawan, 2015). Dugaan tersebut sejalan dengan hasil penelitian Aziz et al. (2020) bahwa aplikasi kitosan dan kekeringan secara bersamaan pada $C$. annuum cv. Lado menyebabkan penutupan stomata yang paling tinggi di antara perlakuan kekeringan dan kitosan secara terpisah maupun kontrol. Hal ini dapat menyebabkan efisiensi fotosintesis menurun karena terbatasnya absorbsi $\mathrm{CO}_{2}$ ke dalam sel-sel tanaman dan juga menginduksi gugurnya organ tanaman. Maser et al. (2018) menjelaskan bahwa ABA yang terinduksi karena kekeringan maupun aplikasi kitosan menyebabkan tingginya akumulasi ion $\mathrm{Ca}^{2+}$ di dalam sel penjaga dan keluarnya ion $\mathrm{K}^{+}$ yang terus menerus. Hal ini berdampak pada penurunan tekanan turgor sel penjaga sehingga stomata menutup.

\section{Aplikasi kitosan saat kekeringan meningkatkan ekspresi gen WRKY17 dan WRKY53}

Gen target WRKY17 dan WRKY53 serta gen referensi CaUbi3 diamplifikasi menggunakan primer spesifik yang telah didesain sebelumnya. Dengan menggunakan primer tersebut akan diperoleh amplikon dengan ukuran \pm 181 bp untuk gen WRKY17, \pm 192 bp untuk gen WRKY53 dan \pm 201 bp untuk gen CaUbi3. Gen referensi CaUbi3 digunakan untuk mengkonfirmasi keberhasilan sintesis cDNA dan sebagai housekeeping gene pada proses qPCR untuk normalisasi level ekspresi gen (Livak \& Schmittgen, 2001). Apabila cDNA berhasil disintesis, maka akan muncul pita tunggal sesuai dengan ukuran yang dirancang untuk masing-masing pasangan primer. Hasil amplifikasi gen target divisualisasikan sesuai pada Gambar 2 . Setelah dilakukan analisis sequencing terhadap produk PCR mengunakan teknik BLAST, diperoleh nilai kesamaan (identity) sebesar $100 \%$ dengan gen Capsicum annuum probable WRKY17 (Accession number: XM_016699929.1) dan WRKY53 (Accession number: NM_001324692.1).

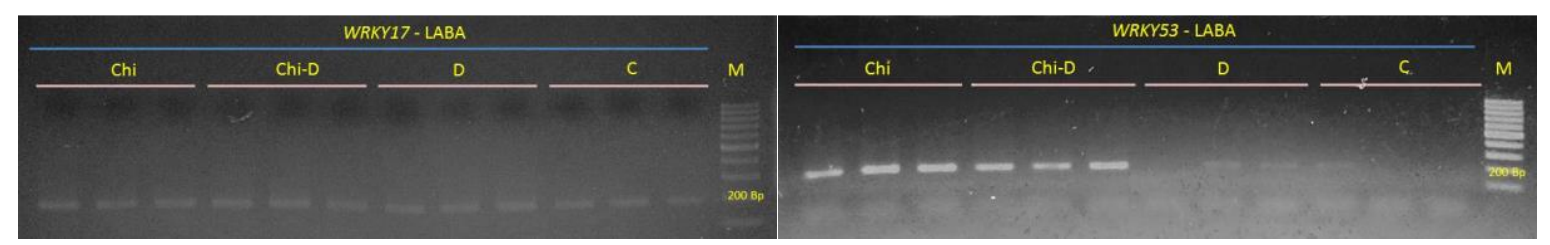

Gambar 2. Elektroforegram gen WRKY17 dan WRKY53 tanaman C. annuum cv. Laba. Chi $=1 \mathrm{mg} \mathrm{mL}^{-1}$ kitosan; Chi-D = $1 \mathrm{mg} \mathrm{mL}^{-1}$ kitosan dan kekeringan; $\mathrm{D}=$ kekeringan; $\mathrm{C}=$ kontrol; $\mathrm{M}=$ marker; dan $\mathrm{K}-=$ kontrol negatif

Figure 2. The electroforegram of WRKY17 dan WRKY53 genes of C. annuum cv. Laba. Chi $=1 \mathrm{mg} m L^{-1}$

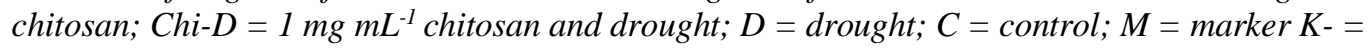
negative control 
Pada saat tercekam, tanaman dapat melakukan berbagai mekanisme pertahanan yang melibatkan integrasi molekuler, seluler, dan biokimia (Khan et al., 2014). WRKY merupakan salah satu kelompok faktor transkripsi yang berperan dalam meregulasi respons kekeringan melalui berbagai mekanisme seperti penutupan stomata, pengaturan level ROS, aktiviasi ABA signaling, dan lain lain (Phukan et al., 2016; Niu et al., 2012). Berdasarkan jumlah dan tipe domain $W R K Y$-nya, faktor transkripsi WRKY pada Arabidopsis telah dikelompokkan ke dalam tiga grup yaitu Grup III yang dicirikan dengan satu motif C-C-H-C zinc finger, grup II dengan satu motif C-C-H-H zinc finger, dan grup I dengan dua motif C-C-H-H zinc finger (JournotCatalino et al., 2006). Beberapa anggota dari masing-masing grup diketahui memiliki peran ganda dalam merespons cekaman biotik maupun abiotik, sebagai contoh WRKY17 (grup II) pada tanaman Arabidobsis thaliana yang diketahui mengalami peningkatan ekspresi setelah diinduksi patogen Pseudomonas syringae (Journot-catalino et al., 2006). Selain itu, overekspresi WRKY17 dapat meregulasi respon kekeringan (Yan et al., 2014). Mekanisme biologis tersebut berkaitan dengan aspek pertumbuhan, perkembangan, dan level cekaman yang dialami tanaman. Berdasarkan hasil penelitian sebelumnya, WRKY41, WRKY70, dan WRKY1 dilaporkan dapat meningkatkan toleransi terhadap cekaman kekeringan pada tanaman tembakau transgenik dengan meregulasi penutupan stomata dan level ROS. Selain itu, Overekspresi WRKY53 pada Arabidosis menunjukkan penurunan toleransi terhadap cekaman garam. Sementara itu, beberapa gen $W R K Y$ terinduksi oleh cekaman kekeringan, sebagai contoh gen-gen $W R K Y$ dari kacang kedelai meningkatkan toleransi cekaman abiotik pada tanaman Arabidopsis transgenik (Niu et al., 2012; Phukan et al., 2016).

WRKY53 merupakan kelompok faktor transkripsi WRKY grup III yang terinduksi saat cekaman kekeringan (Sun \& Yu, 2015), sementara itu WRKY17 diketahui berperan dalam mekanisme seluler terkait toleransi terhadap kekeringan melalui ABA signaling, penutupan stomata dan regulasi level ROS (Yan et al., 2014). Berdasarkan hasil penelitian dapat diketahui perbedaan level ekspresi gen WRKY17 dan WRKY53 yang signifikan antar perlakuan. Kedua gen tersebut teramati mengalami peningkatan level ekspresi secara signifikan terhadap kontrol. Peningkatan level ekspresi paling tinggi terjadi pada kelompok perlakuan kitosan secara individu (Chi), untuk WRKY17 dan WRKY53 masing-masing sekitar 23 dan 52 kali lipat lebih tinggi dibandingkan kontrol, kemudian disusul kelompok kombinasi kitosan dan kekeringan (Chi-D) yaitu sekitar 10 dan 22 kali lipat lebih tinggi dibandingkan kontrol dan kelompok kekeringan (D) sekitar 4 dan 6 kali lipat lebih tinggi dibandingkan kontrol (Gambar 3). Hal ini didukung oleh penelitian sebelumnya bahwa WRKY17 pada tanaman jagung mengalami peningkatan level ekspresi setelah 12 jam perlakuan kekeringan (Cai et al., 2017). Namun demikian, Aziz et al. (2020) menyatakan bahwa WRKY17 pada C. annuum cv. Lado mengalami penurunan level ekspresi sebesar 0,56 kali lipat lebih rendah dibandingkan kontrol setelah diberikan kombinasi kitosan dan kekeringan. Oleh sebab itu, diduga antara cabai merah cv. Laba dan Lado, yang diketahui memiliki perbedaan karakter ketahanan, menunjukkan peran yang berbeda terhadap cekaman yang diberikan.
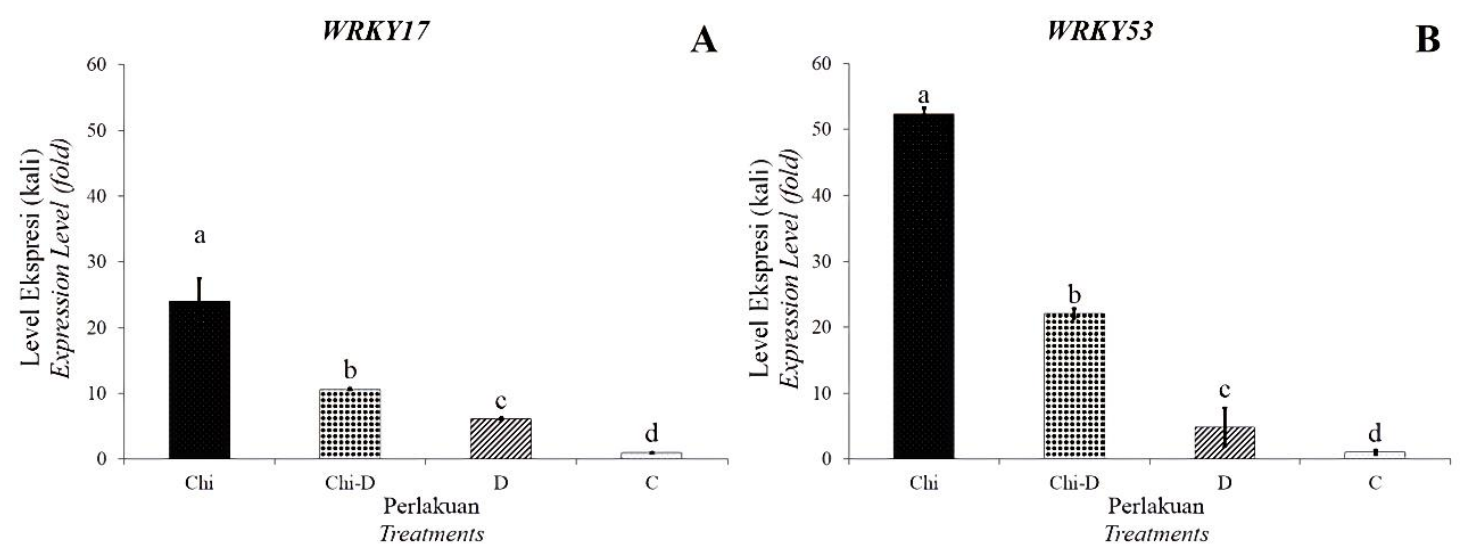

Gambar 3. Pengaruh kombinasi kitosan dan kekeringan terhadap level ekspresi gen WRKY17 (A) dan WRKY53 (B) tanaman cabai merah. Bar pada setiap kelompok perlakuan merepresentasikan standar eror dari nilai rata-rata $(n=3)$. Nilai signifikan ditentukan oleh perbedaan huruf pada setiap bar dengan $p<0,05$. Chi $=1 \mathrm{mg} \mathrm{mL}^{-1}$ kitosan; Chi-D $=1 \mathrm{mg} \mathrm{mL}^{-1}$ kitosan dan kekeringan; $\mathrm{D}=$ kekeringan; $\mathrm{C}=$ kontrol

Figure 3. The effect of chitosan and drought combination on the expression level of WRKY17 (A) and WRKY53 (B) genes on red chili plant. The bars represent the mean of each gene expression level with corresponding standard error $(n=3)$. Significant value is indicated by the letter on top of

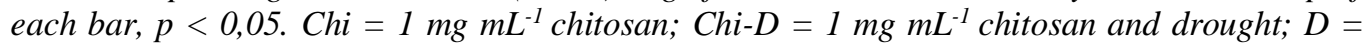
drought; $C=$ control 
Berdasarkan hasil penelitian, baik WRKY17 maupun WRKY53 selalu menunjukkan level ekspresi yang lebih tinggi pada perlakuan dengan kitosan yaitu sekitar 23 (Chi) dan 10 (Chi-D) kali lipat lebih tinggi dibandingkan kontrol untuk WRKY17 dan sekitar 52 (Chi) dan 22 (Chi-D) kali lipat lebih tinggi dibandingkan kontrol untuk WRKY53. Yan et al. (2014) menyatakan bahwa pada kelompok overekspresi WRKY17, saat diberikan aplikasi exogenous ABA menunjukkan berkurangnya sensitivitas ABA signaling terhadap penutupan stomata. Sun \& Yu (2015) menambahkan bahwa WRKY53 diduga meregulasi buka-tutup stomata melalui 2 jalur yaitu dengan mereduksi kadar $\mathrm{H}_{2} \mathrm{O}_{2}$ untuk menghalangi penutupan stomata dan meningkatkan degradasi amilum menjadi malat untuk menjaga agar stomata tetap terbuka. Oleh sebab itu, diduga korelasi ekspresi $W R K Y$ terhadap performa pertumbuhan cabai merah cv. Laba berlangsung melalui jalur tersebut. Berdasarkan analisis korelasi, ditunjukkan bahwa antara gen WRKY17 dan WRKY53 memiliki korelasi positif sebesar $r=$ 0,99 . Dengan demikian, antar dua gen tersebut diduga memiliki peran sinergis dalam merespons cekaman yang diberikan melalui regulasi bukatutup stomata. Hal ini berbeda dengan hasil penelitian Aziz et al. (2020), bahwa gen WRKY17 dan WRKY53 pada cabai merah cv. Lado menunjukkan korelasi negatif sebesar $r=-0,78$ setelah diberikan aplikasi kitosan saat kekeringan, sehingga hasil tersebut membuktikan bahwa cabai merah cv. Laba menunjukkan respons yang berbeda dengan cv. Lado dalam menanggapi kombinasi perlakuan tersebut.

Faktor transkripsi $W R K Y$ terlibat dalam aspek pertumbuhan dan perkembangan tanaman, serta sensitif terhadap cekaman (Niu et al., 2012). Pada kelompok Chi, stomata yang terbuka dapat berdampak positif terhadap pertumbuhan seiring tersedainya $\mathrm{CO}_{2}$ sebagai bahan baku fotosintesis (Iriti et al., 2009). Disisi lain, aplikasi kitosan diketahui berdampak positif terhadap pertumbuhan dan ketahanan tanaman terhadap cekaman, sehingga level ekspresi $W R K Y$ yang tinggi pada kelompok Chi diduga berkaitan dengan respons pertumbuhan yang teramati paling baik pada parameter jumlah daun dan jumlah buah dibandingkan kelompok lainnya. Hal ini sejalan dengan hasil analisis korelasi yang mana antar dua parameter tersebut menunjukkan korelasi positif sebesar $r=0,86$. Namun demikian, pada saat kekeringan (Chi-D \& D) tanaman perlu melakukan mekanisme adaptif untuk mempertahankan ketersediaan air yang terbatas, sementara stomata yang terbuka dapat berakibat buruk bagi tanaman seiring terjadinya kehilangan air (Aziz et al., 2020). Oleh sebab itu, hal tersebut memberikan indikasi bahwa ekspresi gen-gen WRKY berkorelasi positif dengan ketahanan tanaman terhadap cekaman kekeringan dan respons tanaman dalam mempertahankan kesintasannya.



Gambar 4. Analisis korelasi antar parameter setelah kombinasi perlakuan kitosan dan kekeringan pada tanaman cabai merah. Korelasi positif ditunjukan dengan warna jingga, sementara korelasi negatif dengan warna jihau. Daun = jumlah daun; \% B-B = konversi persentase bunga menjadi buah; Buah = jumlah buah; WRKY17 = level ekspresi gen WRKY17; WRKY53 = level ekspresi gen WRKY53

Figure 4. The correlation analysis among parameters after chitosan and drought treatments combination on red chili plants. The positive correlation is defined by the orange color, while the negative correlation is by the green. Daun = the number of leaves; $\% B-B=$ the percentage of flower to fruits conversion; Buah = the number of fruits; WRKY17 = the expression level of WRKY17; WRKY53 = the expression level of WRKY53. 


\section{Kesimpulan}

Berbeda dari cv. Lado, tanaman Capsicum annuum cv. Laba yang diberikan aplikasi kitosan $1 \mathrm{mg} \mathrm{mL} \mathrm{m}^{-1}$ saat berada pada kondisi cekaman kekeringan menunjukan pengaruh yang signifikan terhadap peningkatan level ekspresi WRKY17 dan WRKY53, yaitu sebesar 10 dan 22 kali lipat lebih tinggi dibandingkan kontrol, secara berturut-turut. Namun demikian, penurunan respons pertumbuhan teramati pada parameter jumlah daun dan jumlah buah, yang kemudian diikuti parameter tinggi tanaman yang mana sejalan dengan kultivar tetuanya yaitu Lado yang juga menunjukan respons penurunan karakter pertumbuhan. Namun, aplikasi kitosan secara individu teramati cenderung menunjukkan peningkatan produktivitas pada kultivar Laba.

\section{Ucapan Terimakasih}

Penelitian ini didanai oleh Lembaga Pengelola Dana Pendidikan (LPDP) tahun 2018, Kementerian Keuangan Republik Indonesia. Benih cabai merah kultivar Laba diperoleh dari PT East West Seed Indonesia. Dr. Turhadi, M.Si., yang telah membantu dalam menganalisis data.

\section{Daftar Pustaka}

Anjum SA, X Xie, L Wang, MF Saleem, C Man \& W Lei (2011). Morphological, physiological, and biochemical responsses of plants to drought stress. African Journal of Agricultural Research 6(9), 2016-2032.

Aziz MA, RE Esyanti, K Meitha, FM Dwivany \& HH Chotimah (2020). Chitosan suppresses the expression level of WRKY17 on red chili (Capsicum annuum) plant under drought stress. Indonesian Journal of Biotechnology 25(1), 52-60.

Balitbang (2016). Pengendalian Penyakit Antraknose pada Tanaman Cabai. Juli 11, 2016 Diunduh dari http://www.litbang.pertanian.go.id/berita/one/ 2630/. [21 Agustus 2017]

Bistgani ZE, SA Siadat, A Bakhshandeh, AG Pirbalouti \& M Hashemi (2017). interactive effects of drought stress and chitosan application on physiological characteristics and essential oil yield of Thymus daenensis celak. The Crop journal 5, 407-415.

Cai R, W Dai, C Zhang, Y Wang, M Wu, Y Zhao, Q Ma, Y Xiang \& B Cheng (2017). the maize WRKY transcription factor ZmWRKY17 negatively regulates salt stress tolerance in transgenic Arabidopsis plants. Planta 246(6), 1215-1231.

Chookhongkha N, S Miyagawa, Y Jirakiattikul \& S Photchanchai (2012). Chili growth and seed productivity as affected by chitosan. International Conference on Agriculture Technology and Food Sciences (ICATFS) 1718 Nov 2012.

Ding ZJ, JY Yan, GX Li, ZC Wu, SQ Zhang \& SJ Zheng (2014). WRKY41 controls arabodopsis seed dormancy via direct regulation of $A B I 3$ transcript levels not downstream of ABA. The Plant Journal 79, 810-823.

Dorji K, MH Behboudian \& JA Zegda-dominguez (2005). Water relations, growth, yield, and fruit quality of hot pepper under deficit irrigation and partial rootzone drying. Scientia Horticulturae 104(2), 137-149.

Dzung NA, VTP Khanh \& TT Dzung (2011). Research on impact of chitosan oligomers on biophysical characteristic, growth, development, and drought resistance of coffee. Carbohydrate Polymers 84(2), 751-755.

El-Tanahy AMM, AR Mahmoud, M Mona, AbdeMouty \& AH Ali (2012). Effect of chitosan doses and nitrogen sources on the growth, yield and seed quality of cowpea. Australian Journal of Crop Science 6(4), 115-121.

Esyanti RR, FM Dwivany, S Mahani, H Nugrahapraja \& K Meitha (2019). Foliar application of chitosan enhances growth and modulates expression of defense genes in chili pepper (Capsicum annuum L.). Aust J Crop Sci 13(1), 55-60.

Golldack D, C Li, H Mohan \& N Probst (2014). Tolerance to drought and salt stress in plants: unrevealing the signal networks. Frontiers Plant Science 5(151), 1-10.

Iriti M, V Picchi, M Possomi, S Gomarasca, N Ludwig, M Gargano \& F Faoro (2009). Chitosan antitranspirant activity is due to absisic acid-dependent stomatal closure. Environmental and Experimental Botany 66(3), 493-500.

Jang E, E Gu, B Hwang, C Lee \& J Kim (2012). Chitosan stimulates calcium uptake and enhances the capability of chinese cabbage plant to resist soft rpt disease caused by Pectocacterium carotovorum spp. carotovorum. Korean Journal of Horticultural Science and Technology 30(2), 137-143.

Jiang CH, ZY Huang, P Xie, C Gu, K Li, DC Wang, YY Yu, ZH Fan, CJ Wang, YP Wang, YH Guo \& JH Guo (2015). Trans-cription factors WRKY70 and WRKY11 served as regulators in rhizobacterium bacillus cereus ar156-indeced systemic resistance to Pseudomonas syringae pv. Tomato DC3000 in Arabidopsis. Journal of Experimental Botany, 1-18. 
Journot-Catalino N, Somssich, E Imre, D Roby \& T Kroj (2006). The transcription factors WRKY11 and WRKY17 act as negative regulator of basal resistence in Arabidobsis thaliana. The Plant Cell 18, 3289-3302.

Karimi S, H Abbaspour, JM Sinak \& H Makarian (2012). Evaluation of drought stress and foliar chitosan on biochemical characterices of castor bean (Ricinus communis L.). Research Journal of Biological Sciences 7, 117-122.

Kementerian Pertanian (2016). Outlook Komoditas Pertanian Sub Sektor Hortikultura : Cabai. Jakarta, Pusat Data dan Sistem Informasi Pertanian, kementerian Pertanian.

Khan AL, JH Shin, HY Jung \& IJ Lee (2014). Regulation of capsaicin synthesis in capsicum annum L. by Penicillium resedanum LK6 during drought condition. Scientia Horticulturae 175, 167-173.

Livak KJ \& TD Schmittgen (2001). Analisys of relative gene expression data using real time quantitative pcr and the $2^{-\Delta \Delta \mathrm{C}} \mathrm{T}$ method. Methods 25(4), 402-408.

Malekpoor F, AG Pirbalouti \& A Salimi (2016). Effect of foliar application of chitosan on morphological and physiological charactristics of basil under reduced irrigation. Research on Crops 17(2), 354-359.

Malerba M \& R Cerana (2016). Chitosan effects on plant system. International Journal of Molecular science 17(996), 1-15.

Maser P, N Leonhardt \& JL Schroeder (2018). The clickable guard cell: electronically linked model of guard cell signal transduction pathways. Schroader Laboratory, UCSD, diunduh dari laman http://labs.biology. ucsd.edu/schroeder/clickablegc.html [Desember 2018]

Mondal MMA, MA Malek, AB Puteh, MR Ismail, M Ashrafuzzman \& L Naher (2012). Effect of foliar application of chitosan on growth and yield in okra. Australian Journal of Crop Science 6(5), 918-921.

Niu CF, W Wei, OY Zhou, AG Tian, YJ Hao, WK Zhang, B Ma, Q Lin, ZB Zhang, JS Zhang \& SY Chen (2012). Wheat WRKY genes TaWRKY2 and TaWRKY19 regulate abiotic stress tolerance in transgenic arabidopsis plants. Plant, Cell and Environment, 1-15.
Ohta K, S Morishita, K Suda, N Kobayashi \& T Hosoki (2004). Effects of chitosan soil mixture treatment in the seedling stage on the growth and flowering of several ornament plants. Journal of the Japanese Society for Horticultural Science 73(1), 66-68.

Phimchan P, S Techawongstein, S Chanthai \& PW Bosland (2012). Impact of drought stress on the accumulation of capsaicinoids in capsicum cultivars with different initial capsaicinoid levels. HortScience 47(9), 1204-1209.

Phukan UJ, GS Jeena \& RK Shukla (2016). WRKY transcription factor: molecular regulation and stress responsses in plants. Frontiers In Plant Science 7(760), 1-14.

Pichyangkura R \& S Chadchawan (2015). Biostimulant activity of chitosan in horticulture. Scientia Horticulturae 196, 49-65.

Restiana S (2016). Induksi Peningkatan Capsaicin Pada Cabai Merah (Capsicum annum L. cv. Gada F1) dengan Perlakuan Cekaman Air Untuk Peningkatan Ketahanan Terhadap Jamur Colletotricum acutatum J. H. Skripsi, Institut Teknologi Bandung.

Salachna P \& Zawadzinska (2014). Effect of chitosan on plant growth, flowering, and corms yield of potted freesia. Journal of Ecological Engineering 15(3), 97-102.

Sumarni N \& A Muharam (2005). Budidaya Tanaman Cabai Merah. Bandung, Balai Penelitian Tanaman Sayur.

Sun Y \& D Yu (2015). Activated expression of AtWRKY53 negatively regulates drought tolerance by mediating stomatal movement. Plant Cell Report, 34(8), 1295-1306.

Sung Y, YY Chang \& NL Ting (2005). Capsaicin biosynthesis in water-stressed hot pepper fruits. Botanical Bulletin of Academia Sinica 46(1), 35-42.

Yan H, H Jia, X Chen, L Hao, H An \& X Guo (2014). The cotton WRKY transcription factor GhWRKY17 Functions in drought and salt in transgenic Nicotiana benthamiana through ABA signaling and the modulation of reactive oxygen species production. Plant and Cell Physiology 55(12), 2060-2076. 